\title{
PAKIAH AND SADAKAH: The Phenomenon of Mamakiah Tradition in Padang Pariaman
}

\author{
Novizal Wendry, Sri Chalida \\ Fakultas Ushuluddin UIN Imam Bonjol \\ Jl. Mahmud Yunus, Lubuk Lintah Padang, Sumatera Barat, 25151 \\ e-mail: novizal_wendry@yahoo.com, srichalida@gmail.com
}

\begin{abstract}
Abstrak: Pakiah dan Sadakah: Fenomena Tradisi Mamakiah di Padang Pariaman. Artikel ini mengungkap fenomena mamakiah pada komunitas pakiah, santri pesantren tradisional Padang Pariaman. Niimma mengklaim sadakah yang diperoleh oleh pakiah pada beberapa pesantren, diserahkan kepada buya. Penulis menelusuri latarbelakang historis kapan mamakiah terbentuk, faktor-faktor apa yang memotivasi munculnya, serta bagaimana sikap dan respon masyarakat. Melalui pendekatan fenomenologi ditemukan bahwa mamakiah telah eksis semenjak Islam masuk di Ulakan Sumatera Barat sekitar abad kelimabelas. Penulis berargumen bahwa pakiah disuport oleh masyarakat dan institusi. Selanjutnya menurut penulis Pakiah melakukan aktivitas mamakiah untuk memenuhi kebutuhan dasar mereka selama proses belajar di surau. Dua motif lainnya adalah kultural dan pemahaman keagamaan. Penulis menyimpulkan bahwa selain motif di atas, pakiah memiliki modal kultural.
\end{abstract}

\begin{abstract}
This article reveals the phenomenon of mamakiah in pakiah community, students of traditional Islamic boarding school (pesantren) Padang Pariaman. Niimma claims that sadakah obtained by pakiah in some pesantren, submitted to buya. The author traces the historical background to when mamakiah is formed, what factors motivate the emergence, and how the attitude and response of the community. Through the phenomenological approach it is found that mamakiah have existed since Islam entered Ulakan Sumatera Barat around the fifteenth century. The author argues that pakiah is supported by society and institutions. Furthermore, according to the author pakiah perform mamakiah activities to meet their basic needs during the learning process in surau (a simple form of mosque). Two other motifs are cultural and religious understanding. The writer believes that in addition to these motives, pakiah has also a cultural capital.
\end{abstract}

Keywords: pakiah, buya, sadakah, mamakiah tradition 


\section{Introduction}

An Islamic boarding school (pesantren) is a unique and phenomenal institution. The uniqueness of the pesantren can be seen, among others, from social interaction of its elements such as kyai, students (santri), mosque or surau. Dhofier emphasizes the strong relationship of kinship system of the kyais in Javanese pesantren. The kinship system is so strong that it can be categorized as a closed group for they have a principle of endogamous marriage amongst their families. ${ }^{1}$ It is also applied when a son or grandson of kyai and their nearest relatives have a greater opportunity to become kyai. In addition to these is the relation between the kyai and the students. When a kyai dies, for example, the students continue to show their respect by staying in touch with the descendants of the kyai, especially the one who becomes kyai replacing the deceased father. ${ }^{2}$ The social relation between kyai and his students is described by Torkil as patron-client relationship manifested in social, scholarly and economic activities organizations. ${ }^{3}$

A similar phenomenon can be found in traditional surau (pesantren in Java) of Padang Pariaman. In daily life, kyai is called buya or syaikh and the student is called urang siak or pakiah. ${ }^{4}$ The educational institution is traditionally called surau. However, in line with modernization of education, some suraus has changed its name into a pesantren while some continue to use the name surau. One interesting habit of pakiah is mamakiah undertaken during days off from mangaji. Mamakiah is going out of the surau, walking around the surrounding village bringing buntia (sack of flour) and asking for sadakah (charity) from houses or shops along the ways. ${ }^{5}$ Mamakiah activity can only be found amongst traditional boarding school students in Padang Pariaman.

${ }^{1}$ Zamakhsyari Dhofier, "Kinship and Marriage among the Javanese Kyai," in Indonesia, No. 29, (Apr. 1980), p. 51, see also Tradisi Pesantren, Studi Pandangan Hidup Kyai dan Visinya Mengenai Masa Depan Indonesia, Revised Edition (Jakarta: LP3ES, 2011), p. 108.

${ }^{2}$ Dhofier, Tradisi Pesantren, p. 125.

${ }^{3}$ Torkil Saxebol, "The Madurese Ulama as Patrons, a Case Study of Power and Relations in an Indonesian Community" (Disertation, University of Oslo, 2002), p. 104.

${ }^{4}$ The term pakiah is identified with people who study Islam in surau (mosques) with traditional systems. This term is narrowed in meaning to the people who come to houses to ask for donations or contributions from door to door. Azra asserts that the term of pakiah has a negative connotation, namely those who hold strict Islamic traditions and educated at surau. He considers that sociohistorically, the terms Faqih -pakiah-, urang siak, and Faqir are used instead of words students or santri who study in the mosque when the slogan "return to Shari'a" is encouraged. See Azyumardi Azra, Islam Subtantif: Agar Umat tidak Menjadi Buih (Bandung: Mizan, 2010), p. 115, see also Azyumardi Azra, Surau: Pendidikan Islam Tradisional dalam Transisi dan Modernisasi (Jakarta: Logos, 2003), p. 90 and 96, Silfia Hanani, et al., "Surau Minangkabau, Mengembalikan Pendidikan Agama Islam Berbasis Lokal," in Istiqrâ’: Jurnal Penelitian Islam Indonesia, Vol. III, No. 01, 2004, p. 176.

${ }^{5}$ Niimmasubhani, "Tradisi Mamakiah dan Dampaknya terhadap Internal dan Eksternal Kelembagaan Pondok Pesantren Nurul Yaqin Ringan-Ringan Pakandangan Kabupaten Padang Pariaman" (Thesis, Pascasarjana IAIN Imam Bonjol Padang, 2010), p. 99. 
According to Azra, mamakiah is initially performed by pakiah to support their basic needs during their study in the surau. The education of pakiah in the surau is absolutely free of charge, no tuition fee nor accommodation fee or other fees. ${ }^{6}$ On the other hand, the greater part of the community thinks religious learning in the surau does not need special financial attention, for their sustenance will be guaranteed by God. Gradually, mamakiah becomes a form of culture inherited from generation to generation. Because mamakiah is associated with sadakah, the pakiah makes all efforts in order to have a sufficient amount of sadakah. Ade Dasrial for example, tells how he intentionally starts mamakiah very early so that the location where he aims to do mamakiah is not visited upon by other pakiahs. When he accidentally passes the same direction with another pakiah, he rushes to overtake him so that he could earn more sadakah. ${ }^{7}$

Buya, on the other hand, does not ask the pakiah to do mamakiah except in emergencies, to meet their basic needs to ensure the sustainability of their education. However, the content of religious messages conveyed to the public from the surau and mosques around villages emphasize the importance of giving sadakah, especially to those who are in the ways of Allah (fi sabîlillâh). Including in these groups-perhaps even most importantly-is pakiah.

There are some community leaders who do not like the mamakiah activity because it is considered as insulting and degrading to Islam. ${ }^{8}$ However, it cannot be denied that there are many people who look forward to the arrival of pakiah because they want to give sadakah, especially at harvest time and balai day (weekly market day). ${ }^{9}$ Apart from different public responses above, mamakiah has already been passed down from generation to generation. Mamakiah, which initially occurs around Islamic boarding schools in the area of Padang Pariaman, now has spread up to Padang.

In her research, Niimma claims that sadakah obtained by pakiah in Padang Pariaman is given to buya or the leader of the pesantren. The same things happen in the Pesantren of Nurul Yaqin Ringan-ringan which is the object of her research. Niimma, however, suggest that her research left some other lines of studies such as the factors that support the continuity of mamakiah in Padang Pariaman until now, the real motives of pakiah in doing mamakiah, and the public responses to the pakiah and sadakah. Due to the large number of pesantren in Padang Pariaman, the scope of this research is limited to Madinatul Ilmi Islamiyyah Sungai Sarik and Nurul Yaqin Ringan-Ringan assuming that both are large suraus, according to Verkerk Pistorious categorization. ${ }^{10}$

${ }^{6}$ Azra, Surau, p. 96.

${ }^{7}$ Ade Dasrial, former pakiah, interview in Pariaman, April 6, 2016.

${ }^{8}$ Joni Kamal, a community leader in Sikabu Lubuk Alung, a former pakiah, interview in Sikabu Lubuk Alung, April 2, 2016.

${ }^{9}$ Azwirman, a community leader in Limpato Sungai Sariak, interview in Limpato Sungai Sariak, April 2, 2016.

${ }^{10}$ Verkerk Pistorious, a Dutch official who has been to West Sumatra, dividing surau into 
Mamakiah involves elements such as pakiah or students, buya, and people who give sadakah. The result expected from this activity is sadakah which would be used by pakiah. The existence of mamakiah cannot be separated by social domain, where there is a "struggle" for limited access. ${ }^{11}$ Each pakiah is an agent of individual and the pesantren institution who tries to maintain its position in the acquisition and accumulation of capital; cultural, symbolic, and economic capital. In the context of pakiah, such cultural capital, as mentioned by Bourdieu, produces or reproduces a product. ${ }^{12}$ Pakiah does not move in a vacuum but involves situations and social relations. With the cultural capital, the existence of pakiah in the society is a need.

The study of the pesantren community (surau) which is associated with both kiai (buya) and students (pakiah) has been done by previous researchers. Zamakhsyari Dhofier, for example, describes the role of kyai in maintaining and developing networks of pesantren in Java. He also points out to the fact that Islamic understanding of Java pesantren is generated from scholars of fiqh, hadith, tafsîr, theology and sufism of the seventh to twelfth centuries. ${ }^{13}$ In one of the articles, Zamakhsyari also touches on endagamous marriage system amongst families of kyais. ${ }^{14}$ Endang Turmudi reveals three types of kyai in Jombang; kyai of pesantren, kyai of tarekat (sufism), kyai of politics. He argues that the charisma of kyai is limited to religious authority and not on political matters. ${ }^{15}$ Dawam Rahardjo describes the life of students of Pondok Pabelan Muntilan Magelang, which adopts the system of Pondok Modern Gontor. ${ }^{16}$ Meanwhile, Florian conducts an ethnographic research in the Pesantren of al-Muayyad Windan Solo with plural and multicultural character. Florian refuses the notion that the Islamic boarding school is a source of radicalism that spawned militant Muslims as released by the International Crisis Group. ${ }^{17}$

In a study, Linda S. Walbridge maps four typologies of curriculum in three pesantren in Central Java. The first is sorogan in which students sit listening to a briefing of kyai without a formal curriculum. The second is pesantren which implements a classical system. The

three categories; a small surau which has a capacity of 20 pakiahs, a middle size surau with capacity of 80 pakiahs, and a large surau that can accommodate 100 to 1000 pakiahs. Azra, Surau, p. 88.

${ }^{11}$ Richard Jenkins, Membaca Pikiran Pierre Bourdieu, trans. Nurhadi, Editon 6 (Yogyakarta: Kreasi Wacana, 2013), p. 124.

${ }^{12}$ Pierrie Bourdieu, Distinction: A Social Critique of the Judgment of Taste (New York: Routledge, 2006), P. 127. See also Randal Johnson, "Pengantar Pierre Bourdieu tentang Seni, Sastra dan Budaya," in Arena Produksi Kultural, Sebuah Kajian Sosiologi Budaya, trans. Yudi Santosa, Editon 3 (Yogyakarta: Kreasi Wacana, 2015), p. xix.

${ }^{13}$ Dhofier, Tradisi Pesantren.

${ }^{14}$ Dhofier, "Kinship and Marriage among the Javanese Kyai," p. 51

${ }^{15}$ Endang Turmudi, Struggling for the Ummah (Canberra: ANU Press, 2006), p. xvii.

${ }^{16}$ Dawam Rahardjo, "The Life of Santri Youth: A View from Pesantren Window at Pabelan," in Sojourn: Journal of Social Issues in Southeast Asia, Vol. 1, No. 1 (February 1986), p. 43-44.

${ }^{17}$ Florian Pohl, "Islamic Education and Civil Society: Reflections on the Pesantren Tradition in Contemporary Indonesia", in Comparative Education Review, Vol. 50, No. 3 (August 2006), p. 389-409. 
third is pesantren which implements the curriculum of the Ministry of Religious Affairs. ${ }^{18}$ Walbridge illustrates further the everyday life of female students and kyai focusing on the orientation of the santris. The female santris apparently have a rather simple objective, that is, to accuire the right guidance from the kyai. No one wants to set up a pesantren for girls. The vast majority of them want to be the wife of kyai and becomes a nyai. A nyai plays a role as a guide for female students in the pesantren. For Walbridge, Islamic boarding school provides an opportunity for women to be active in politics even though they are obedient to the kyai during their education in the pesantren. ${ }^{19}$

One of researches in relation to contestation in pesantren is done by Torkil Saxebøl for his doctoral research at Oslo University with the object of Islamic scholars in Madura. Torkil concludes that in the context of Madura pesantrens, the relation between kyai and the students takes the form of patron-client. This relationship is manifested in the form of well-being in which the kyai becomes superior with the power or authority he has. Kyai exercises the power and authority in the form of obedience a pupil to the teacher. With the slogan atî $\hat{u}$ wa-sma'û, students are unconsciously "forced" to serve the kyai in daily life. Thus, this relation is not colonizing but taking advantages. ${ }^{20}$ Torkil agrees with van Dijk who presumes that the patron and client relationship in the case of kyai in Madura is also experienced by all Islamic scholars in Indonesia. ${ }^{21}$ The conclusions of van Dijk and Torkil, however, need to be scrutinized further. The present study attempts to contribute on this.

With regard to the practice of sadakah, there have been some researches done in certain cases in other areas of Indonesia, for example a research by Furqan Syarif Hidayatullah and Ichmi Yani Arinda R. Furqan who glance at the portrait of the implementation of sedekah bumi (sedekah for the earth) in Cisampih, Kutabima, Cilacap in the Islamic perspective. According to Furqan, sedekah bumi in Cisampih is an act of gratitude of the community to the Creator who has been giving sustenance to them through the earth they live so that cultivation and other activities that they do could produce good harvests and bring success. Furqan does not deny the incompatibility of the tradition in some part with Islamic teachings because it is an acculturation between pre-Islamic traditions (Hindu-Buddhist) and Islam. ${ }^{22}$ A similar research on the tradition of sedekah bumi (nyadran) is done by Ichmi Yani Arinda R. in the community of Sraturejo, Bojonegoro. In addition to an act of gratitude to the Creator, Ichmi also finds that by this tradition the people feel closer to the Creator, away from disasters

${ }^{18}$ Linda S. Walbridge, The "Santri-Wati" of Indonesia's "Pesantren": Orientations of Students of Three Girls Religious Schools," in Islamic Studies, Vol. 37, No. 4 (Winter 1988).

${ }^{19}$ Ibid., p. 327-328.

${ }^{20}$ Torkil, "The Madurese Ulama as Patrons."

${ }^{21}$ Ibid., p. 11.

${ }^{22}$ Furqon Syarief Hidayatulloh, "Sedekah Bumi Dusun Cisampih Cilacap," in el Harakah, Vol. 15, No. 1, 2013. p. 1-17. 
and obtain a better crop yields. ${ }^{23}$ Although the discussions on sedekah by Furqan and Ichmi are related to the study done by the author, basically, they are different from this study in terms of location and the formal object of research.

Specifically, with respect to the object of this study, it has been reviewed by Niimmasubhani in her research for a master degree. Niima focuses more on the impact of mamakiah tradition on the institution of Pondok Pesantren Nurul Yaqin. According to Niimma, mamakiah is a custom performed by students every Thursday and Friday morning for the continuation of their education at the surau. She notes that among positive impacts of mamakiah are: practicing patience, preaching, helping with the education fee, and increasing gratitude. However, the negative impacts of mamakiah are that it could weaken santri's motivation as well as reduce their learning and break times. Mamakiah is also instrumental in socializing and promoting the pesantren. ${ }^{24}$ In one of her statement, Niima claims that there are differences in utilization of the results of mamakiah or sadakah between what is going on in the Pesantren of Nurul Yaqin and in other traditional pesantrens. In Nurul Yaqin, sedekah is not given to the kiai of the pesantren, while in other traditional pesantren, pakiah gives some of the sedekah to the teachers to help them as they have provided meritorious services nurturing them while they are studying in the pesantren or as an expression of gratitude to the teachers. ${ }^{25}$ Seen from the material objects of discussion, Niimma focuses only on the case of Pesantren Nurul Yaqin without comparing it to other pesantren like Madinatul Ilmi Islamiyyah. Her study is also limited to the impact of the mamakiah activity on the pesantren without highlighting other aspects such as competition amongst pakiahs that may occur.

\section{Research Method}

This descriptive and qualitative research falls in the category of field research. Data is obtained from observations and interviews with pakiah, former pakiah, buya (pesantren leaders), and members of the community. Data collected through observation and in-depth interviews are divided into three stages; the first is preliminary observation which is needed to explore the initial data. The second observation is done simultaneously when the researcher is working in the field, at the location where pakiahs do mamakiah activity as well as in the pesantren where the pakiahs live and study. The third observation is carried out for the purpose of sharpening and validating data. In this case, the researcher conducts Focus Group Discussion involving pakiahs of two sample pesantrens. This study applies unstructured interview in order to obtain data more freely from the pakiah, buya, and the society at large. The research

\footnotetext{
${ }^{23}$ Ichmi Yani Arinda R. "Sedekah Bumi (Nyadran) sebagai Konvensi Tradisi Jawa dan Islam Masyarakat Sraturejo Bojonegoro," in el Harakah, Vol. 16, No. 2, 2014. p. 100-110.

${ }^{24}$ Niimmasubhani, "Tradisi Mamakiah dan Dampaknya terhadap Internal dan Eksternal Kelembagaan Pondok Pesantren Nurul Yaqin Ringan-ringan Pakandangan Kabupaten Padang Pariaman," (Master Thesis IAIN Imam Bonjol Padang, 2010), p. 99-100.

${ }^{25}$ Nimmasubhani, "Tradisi Mamakiah,” p. 90.
} 
is conducted in the district of Padang Pariaman, West Sumatera Province with the samples of pakiah from both the pesantren of Madinatul Ilmi Islamiyyah and the pesantren of Nurul Yaqin.

This study applies the phenomenology approach developed by Husserl stating that an essence can be understood through the investigation of the visible (empirical objects) and manifestation. ${ }^{26}$ In this sense, as revealed by Erricker from the research by Waardenberg, social structure and the behavior of the community—pakiah, buya, and the community members-is displayed based on scientific premises. ${ }^{27}$ With regard to data analysis, it is done based on the stages of data collection, data interpretation, and writing. ${ }^{28}$

\section{The History of Mamakiah Tradition}

The history of pakiah cannot be separated from the introduction of Islam into Minangkabau in $16^{\text {th }}$ century with Sufism characteristic assimilated with social life. ${ }^{29}$ After Islam developed in Minangkabau, the people of Siak came with merchants to the rural areas to spread Islam. They were received by the Minang people as guests and stayed in mosques or surau, where the transmission of science and knowledge to young people of Minang took place. Therefore, urang siak were respected because they were tutors of mangaji (sorogan/ learning religious teachings), they taught how to perform prayers and other Islamic teachings.

Mamakiah activity is done every official holiday from mangaji in surau, namely every Thursday and Friday. Mamakiah is done more often during the month of Ramadan, especially by muqîm (those who stay in the surau) as mangaji in the mosque is closed. Beside due to weekly days off, Thursday and Friday is chosen for mamakiah activity because it based on the understanding of buya and tuangku who believe that giving sadakah on these days has a greater fadhîlah than any other days. They refer to books of Islamic jurisprudence, such as al-Iqnâ':

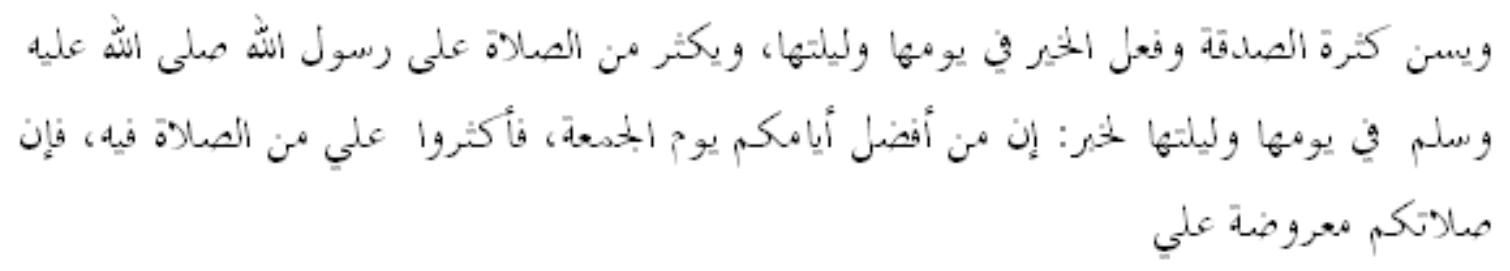

${ }^{26}$ Clive Erricker, "Pendekatan Fenomenologis," dalam Peter Connolly (ed.), Aneka Pendekatan Studi Agama, trans. Imam Khoiri, Editon 3 (Yogyakarta: LKiS, 2011), p. 110.

${ }^{27}$ Ibid., p.106-107.

${ }^{28}$ Lexy J. Moleong, Metode Penelitian Kualitatif (Bandung: Remaja Karya, 1989), p. 4.

${ }^{29}$ Duski Samad, Kontuinitas Tarekat Di Minangkabau (Padang: TMF PRESS, 2006), p. 2. This is also in line with the information from Buya Kerajaan, that the origin of pakiah starting from students who come from areas outside of Padang Pariaman who are generally derived from Siak, Riau Islands now. Buya Kerajaan, one of the Leaders in the Pesantren of Nurul Yaqin, Ringanringan, August 14, 2016. 
It is recommended to multiply the charity and do good works on Friday and Thursday night. Also, it is recommended to multiply saying shalawat to the Prophet Muhammad at night or during the day of Friday, based on the hadith, "Verily the best day is Friday. Therefore, multiply reading shalawat for me because your prayers (shalawat) are shown to me.

The explanation above is in line with the contents of the tuangku religious lectures at the mosque on time and amount of sadakah. In front of the people whose house of are visited mostly by the pakiah, tuangku also confirms that in terms of the value of sadakah, it is not seen from the amount (small or large) of the sadakah, but rather from the intentions of the givers, whether it is given sincerely or not. People should give sadakah sincerely according to their capabilities. It is not wrong when Tuangku Kaciak tells the story of former Islamic scholars in his lecture, in which they gave sadakah secretly. ${ }^{30}$

The vast majority of students who go to the pesantren come from families of middle or low economic level. When they send their children to the pesantren, they pay only initial capital. The initial capitals of new students are usually in the form of mats, pillows, cupboard, sarong and a bag of rice. After that, the provisions given by parents are not followed by other supplies due to economic reasons. Even if there is a supply of rice and side dishes from their parents, it comes once a month and only lasts for three days.

Due to the fact that mamakiah tradition has been started since hundreds of years ago, it seems that there has been a strong bond between pakiah and the people in Padang Pariaman. Parents advise to continue the tradition of sadakah and the reward is awarded to the families who had died. The argument is that what has been gained is to continue the hard work of the previous generation. What is interesting about this tradition is the fanaticism of the community when distributing donations in which they feel more "comfortable" when the receiver of sadakah is a pakiah. This is what has been suggested by parents from generation to generation, that is to diligently give sadakah to pakiah.

\section{Motivations of Doing Mamakiah}

Pakiah's motivation can be divided into three main factors: cultural, economic, and religious understanding factors.

\section{Cultural Factor}

Living together in a surau help unite the word view of the santris. Although the world they see in surau is quite limited, narrow, and some how boring, it prepares them for challenges that they may encounter in their future lives in the real world. In this respect, mamakiah

${ }^{30} \mathrm{~A}$ quote from Indra Saputra Tuangku Kaciak lecture, Surau in Gobah Laweh Lubuk Alung, July 25, 2016. 
can be seen as a time to go and see the outside world. Joy and sorrow during mamakiah activity and the need for continuation of this tradition are the reasons why mamakiah becomes a lasting tradition among students. They share stories about their experiences during mamakiah and the sadakah they obtained as well as the allocation of the sadakah. It is not exaggeration to say that mamakiah has been a culture or tradition that repeatedly done so that it become a blue print for the students. Asked whether mamakiah is recommended in the pesantren, Buya Jalalain states that actually there is no recommendation from the institution. Nevertheless, as it has already been a custom since a long time ago, he sets two days off, Thursday and Friday, which are, then, used for mamakiah. ${ }^{31}$ Similar statement is also made by Buya Kerajaan who says that mamakiah is not officially recommended; it is an initiative of santris. The pesantren requires pakiah to ask permission first before going out for mamakiah.

Basically, the reason why a student actively involves in mamakiah is because they are invited by friends. Generally, those who come to boarding schools such as Madinatul al-Ilmi Islamiyyah and Nurul Yaqin are teenagers of junior high school age. As such, they are in a period of instability and easily influenced by fellow santris, especially the senior ones. According Marfi, he was first invited by fellow students to do mamakiah. ${ }^{32}$ Similarly, Bima, one of the students from Sijunjung, says that he was invited to do mamakiah for the first time by his senior fellow students. ${ }^{33}$ Seen from the area of origin, both Mafri and Bima are students who come from the same area that is Sijunjung.

There are some students who do mamakiah because of envy seeing their fellow students have their supplies for life in the boarding school from mamakiah (sadakah). Therefore, they are advised by his friends to do mamakiah. There are also some pakiah who intentionally count their money they get from mamakiah (sadakah) in front of his friends, other students. They count the money by fanning them in the presence of their friends. ${ }^{34}$ This action would cause "turmoil" among students who have never done mamakiah. The unstable psychological condition is reinforced by financial condition that is far from enough. In short, because of the habits and thinking that they can survive independently like their friends who do mamakiah, other students who had never done mamakiah are triggered to participate in doing so.

\section{Economic Factor}

It is undeniable that economic factors are driving the perpetuation of mamakiah activity. The large number of students who comes from low economic level background could not be dealt with by the internal institution of the boarding schools. This makes the manager of the pesantren allow the students to do mamakiah. Buya Kerajaan and Tuanku Aznam

\footnotetext{
${ }^{31}$ Interview with Buya Jalalain, August 14, 2016.

${ }^{32}$ Interview with Marfi (not the real name), September 23, 2016.

${ }^{33}$ Interview with Bima (not the real name), September 23, 2016.

${ }^{34}$ Interview with Donal (not the real name), September 24, 2016.
} 
said that mamakiah is the last alternative to resolve the economic problems among students. Students have a strong desire to learn religious teachings in boarding schools, on the other hand, they have financial constrains for mangaji, in terms of both tuition fee and living expenses during their stay at the boarding schools. Buya acknowledged that the boarding schools make an effort to minimize mamakiah activity by requiring students to ask permission first. He said that he only gives permission for pakiah who run out of supplies to do mamakiah. ${ }^{35}$

It is also revealed by Buya Jalalain, Head of Pesantren Madinatul Ilmi Islamiyyah. According to him, life is now hard, so he does mamakiah. Buya Jalalain even invites those who are able to overcome the economic crisis among his students. Buya admits that there is a grant for Bantuan Operasional Sekolah (the operational fund of schools) and for students with a good achievement from the Ministry of Religious Affairs. However, he explicitly rejects it because there is no help from the government without any string attached. He does not want the education system at his pesantren to be interfered or controlled by the Ministry of Religious Affairs. According to Buya, if the BOS fund was received, the pesantren would be required to use the curriculum of the Ministry of Religious Affairs. This does not fit with the materials that have been taught continuously from generations to generations at the pesantren. ${ }^{36}$

The explanation of Buya Jalalain seems to be in line with the statement of students or pakiah that the researcher met. Marfi (not the real name) says that sometimes Buya "asks" students to do mamakiah. This is done, however, as the last choice to deal with financial problems when most of the students studying in his pesantren run out of provisions. The majority of students of this pesantren come from out of town and their parents provides no sufficient financial support. Basically the pesantren of Madinatul Ilmi Islamiyyah does not charge the students with a high cost of education. According to Genta, the monthly tuition fee is only IDR30,000.00 each plus two liters of rice. They are not charged for other items such as power, housing, and papers like commonly collected by other schools in general. However, because the majority of students come from outside the area and they run out of their living costs which should be supplied by their parents, they are allowed to do mamakiah. ${ }^{37}$

Based on an investigation of several samples of pakiah of the pesantren of Madinatul Ilmi Islamiyyah, it is revealed that on average they come from outside the area of Padang Pariaman like Sijunjung and Damashraya. Some of them do not receive money from their parents. Mafri, for example, with his brother who is also mangaji in the boarding school can only expect and wait for money or other supplies from his brother who has had a family and works as a technician at a motorcycle repair shop. ${ }^{38}$ Similar cases can be commonly found in traditional pesantren in Padang Pariaman. Generally, those who mangaji in a boarding

\footnotetext{
${ }^{35}$ Interview with Buya Kerajaan, August 14, 2016.

${ }^{36}$ Interview with Buya Jalalain, August 14, 2016.

${ }^{37}$ Ibid.

${ }^{38}$ Interview with Mafri (not the real name), August 14, 2015.
} 
school help promoting the existence of their boarding school when it is holiday or do mamakiah in his hometown. This promotion seems to be so successful that the regenerations from years to years continue to do the same. Another case is also experienced by Welfi, who claims that he rarely receives supplies from his parents. Even if there are some, they are not enough to cover his daily needs. ${ }^{39}$

\section{Religious Understanding Factor}

To see normative arguments underlying and motivating students from both pesantrens in doing mamakiah, it is important to see how the concept of sadakah envisaged in religious texts is understood and practiced by pakiah. From the data of buyas and tuankus' lectures in surau and mosques collected by the researcher, it is found that sadakah is one of good deeds of which the rewards from the God would never end. The practice of sadakah includes the perpetual donation (shadaqah jâriyah).

Yang terakhir, sadaqah jariyah. ....ado sadakah wajib, ado sadakah sunaik. Nan wajib tu zakat, bakatak an. Tapi kalau sadakah sunaik ndak ado bakatak an doh. Tapi yang dimaksud sadakah jariyah tu apo? Yaitunyo wakaf. Wak wakafan karambieh sabatang, salagi dipakai urang, ateh namo kebaikan, tu mangalir pahalonyo ka awak tu. Kok karambie agak sabatang, batu agak ciek, tu sadakah namonyo tu. Ko sadakah batu ka surau, sa oto ndak talok dek wak doh, wak baok ce ciek dari batang aie, lah jadih tu. Nyo ndak bakatak an doh. Samo jo maapeh, tagantuang umpan e. Kalau katak umpan ne, dapek rutiang. Yang pantiang umpan e. ${ }^{40}$ [The latter, shadaqah jâriyah. ... there are obligatory and recommended charities. The obligatory charity is known as zakat. It is given out in certain portions when reaching predetermined sum (nishâb) while the portion of shadaqah is not determined. What is meant by the shadaqah jâriyah (perpetual shadaqah)? That is an endowment (waqaf). We give a coconut tree as waqaf, as it can be used by others for something good, the reward continues to flow to us. Like the coconut tree, a stone can also be given for charity. Give stone for charity to surau, if we cannot give a car of stone for charity, it is enough for us a stone from the river. It is no measurement of such charity. Just like fishing, it depends on the bait. If the bait is frog, we could get snakehead fish. What is important is the bait.]

The content of Tuanku Sidi Ibrahim's lecture above exemplifies the importance of giving sadakah, of both obligatory and recommended sadakah. The recommended sadakah is given in portions that are not predetermined and in accordance with the ability of the person who gives the sadakah. As far as the sadakah is used by many people, the reward from the God will flow continuously. One of the types of sadakah is donating a stone for construction of a surau. In the context of the people of Padang Pariaman, for constructing

${ }^{39}$ Interview with Welfi (not the real name), Saturday, September 23, 2016.

${ }^{40} \mathrm{~A}$ quote of Muhammad al-Munawwir Tuanku Sidi Ibrahim lecture, in the Mosque of Sungai Bayiah Sei. Sariak, July 20, 2016. 
a surau or a mosque, typically, a location near a river is chosen so that the water can be supplied to the mosque. Therefore, the preacher gives a simple example that for the community of low economic level, sadakah can take the form of taking stones from the river to the mosque yard for the construction of the mosque.

Tuangku Abdul Hadi, one of the community leaders and former pakiah confirms that the essence of pakiah who do mamakiah is to encourage people to give sadakah and not asking for sadakah. Originally, pakiah say "basadakah lah, Mak basadakah lah, Pak" bukan"sadakah, Mak, sadakah Pak". ${ }^{41}$ The first phrase means, "Would you give out sadakah, Madam, Would you give out sadakah, Sir." while the latter means, "Give me sadakah, Madam and Sir." The first phrase is essentially in line with the verse which orders us to take sadakah from muzakki (those who are obliged to give zakat), as described by Buya Kerajaan of Pesantren Nurul Yaqin. ${ }^{42}$

The above explanation legitimizes that mamakiah is essentially telling people to give out sadakah and pakiah is an arm of the government to collect the sadakah. On the other hand, pakiah is mustahiqq, the person entitled to receive sadakah, because he is categorized as fi sabîlillâh in the religious term. Beside as the sadakah collector, pakiah is also considered as one who practices sadakah because he prays for those who give the sadakah every time he receives it.

\section{The Views of Community on Pakiah and Sadakah}

Self-actualization of a student as pakiah does not necessarily make him as pakiah of a lifetime. It would change in accordance with the personal growth of the student when he grows mature in thinking and acting. A pakiah would change when he realizes the manifestation of himself as a cadre of the villagers and citizens who once have given him sadakah. At the time of doing mamakiah, a pakiah is seen bluntly as a person with lower class in the society compared with those who give sadakah. As a matter of fact, the pakiah also feels ashamed and aspires to become giver of sadakah if later he could manage to become a successful person.

After completing his education in a pesantren, pakiah usually no longer go to the field to do mamakiah. He discovers his true identity and is confirmed as tuangku in a traditional ceremony held at his boarding school. The ceremony is usually attended by community leaders, buya as leader of pesantren, and accompanied by a salawaik dulang feast in the boarding school. Once back into the community, a former pakiah would be a tuangku who is respected by the community. A tuangku functions as an imam at mosques and surau, and religious teacher for his community.

\footnotetext{
${ }^{41}$ Interview with Tuangku Abdul Hadi, August 21, 2016.

${ }^{42} \mathrm{~A}$ lecture of Buya Kerajaan in the mosque of Ringan-ringan, July 29, 2016.
} 
A tuangku is the person to ask questions about religious matters. Sometimes, a tuangku also consulted about social and political issues of the community. Tuangku's close tie with the community is reminiscent of the relation between pakiah and the 'client' society that had given him sadakah. In short, there occurs an evolution of which a student who becomes pakiah (asking sadakah) subsequently changes to a person who provides 'sadakah' in a different form, namely religious opinions, advices and services.

Robiah, one of residents of Lubuk Alung says that frequently, a pakiah which has become a 'client' in the village is later crowned as tuangku by the local community. ${ }^{43}$ After the coronation, of course, the arrival of the former pakiah would be always expected to provide advices on the teachings of religion in certain days. It is also revealed by Dedi, a pakiah who is very young. According to Dedi, his presence in his hometown, where he was sent to mangaji to Nurul Yaqin is always awaited for to be a priest substituting the local tuangku when he is absent for certain reasons, such as going out of town. ${ }^{44}$

Community views on the issue can be classified into two kinds; positive and negative. A positive response is indicated, among others, by Ronal who considers pakiah with their routine of going around the village on Thursdays and Fridays constitute a mental training for the santris. Various attitudes of society during mamakiah help pakiah in developing a determined personality which in turn prepares him to become a succesful when preaching in a plural society. The same thing is also confirmed by Tuangku Abdul Hadi, a former pakiah and board of Nahdlatul Ulama in Padang Pariaman that mamakiah has a positive impact on pakiah due to the mental training. ${ }^{45}$ In addition, pakiah are also trained to be generous among them. This opinion is also expressed by Ronal, the owner of a rice mill. According to him, not all pakiah come from the less fortunate family. Many of them also come from those of upper middle class, so they often share or give the sadakah they get from mamakiah to their friends who need it in the surau. So, many villagers wait for the arrival of pakiah, as revealed by Uni Ida, one of residents of Kayu Gadang Sikabu Lubuk Alung. ${ }^{46}$

According to Zainal Tuangku Mudo, basically mamakiah can be categorized as an emergency, it is permitted under a dire conditions only. This is, according to Zainal, when pakiah is viewed in the context of khudz min amwâlihim shadaqah (take alms out of their possessions) ${ }^{47}$ This means that pakiah can be considered as collector of sadakah from the people, door to door. The logic behind the opinion that pakiah is permitted is also revealed by Tuangku Abdul Hadi who considers pakiah, in principle, as carrying out a noble task, that is to invite people to give charity. However, He requires that those who would be given

\footnotetext{
${ }^{43}$ Interview with Robiah Adawiyah, August 19, 2016.

${ }^{44}$ Interview with Dedi (not the real name), August 19, 2016.

${ }^{45}$ Interview with Tuangku Abdul Hadi, August 11, 2016.

${ }^{46}$ Interview with Uni Ida, August 19, 2016.

${ }^{47}$ Interview with Zainal Tk. Mudo, the chairman of the Indonesian Council of Ulama (MUI) Padang Pariaman, August 19, 2016.
} 
permission for doing mamakiah are senior students, they are the grade five and up because they would become tuangku who will directly meet people in the community. Therefore, they need a mental training such as mamakiah. ${ }^{48}$

In another perspective, pakiah can be viewed as "lower hands" (al-yad al suflâ) or the receifient, as stated in a hadith "upper hands" is better than "lower hands" which means it is better to give than to receive (al-yadu al-"ulyâ khair min al-yad al-suflâ). ${ }^{49}$ When viewed from this perspective, mamakiah is not a good practice because the religion states that giving is better than receiving. The same opinion is also expressed by Tuangku Abdul Hadi who says that the current activity of mamakiah tends to be interpreted as begging because it uses the phrase, "Sadakah Sir, Mom!". Although it is viewed negatively, the two former pakiahs do not admit that the government has not been able to overcome the financial problems of the students in the surau or pesantren. Badan Amil Zakat Daerah (the fund of the Regional Tithe Council) in Padang Pariaman set up by the government is inadequate to cover the education fee of the pakiah in the boarding schools. ${ }^{50}$ In addition to the above reasons, the community is already close to the pakiah, who come to collect their sadakah even in a very small amount. Therefore, if the activity is stopped, some people will sure to miss it.

The differing responses toward mamakiah activity should be seen in the light of rich diversity of the population of Padang Pariaman. As noted earlier, the pakiah often crose the boundaries of Padang Pariaman in doing mamakiah. Diverse educational backgrounds and professions form different views on pakiah. There are those who see it as positive, some who views it negative, and there are also those who sit on the fence. Generally, those who see pakiah positively consist of people who like to give charity and are generous either they are rich or poor. Based on the exploration of the researcher to the region of Sikabu Padang Pariaman, generally they expect and look forward to the arrival of pakiah. Uni Ina, for example, who is a porridge seller at Sikabu, believes that giving sadakah to the pakiah gives her special blessing. She says that every time she gives sadakah to pakiah, she is always rewarded with a prayer by pakiah wishing that she would be rewarded double by Allah for what he had given as sadakah. ${ }^{51}$ For this reason, the presence of pakiah is always awaited by the public.

Those who see mamakiah as negative activity generally come from urban public. There are only a small number of people in Padang Pariaman who support this view. As said by Mafri that people who do not like pakiah, always judge them negatively. Some of them give the pakiah a hoe when he comes asking him to work to earn money with his own hands. ${ }^{52}$ There are also people who believe that the phenomenon of mamakiah done by pakiah is common

\footnotetext{
${ }^{48}$ Interview with Tuangku Abdul Hadi, August 11, 1916.

${ }^{49}$ Interview with Zainal Tk. Mudo, August 19, 2016.

${ }^{50}$ Ibid.

${ }^{51}$ Interview with Uni Ina, Sikabu Lubuk Alung, August 11, 2016.

${ }^{52}$ Interview with Mafri (not the real name), August 14, 2015.
} 
and has become a tradition. These groups of people usually neither expect too much nor reject the arrival of pakiah.

People have different views on what the sadakah is used for. Niimma asserts that sadakah obtained by pakiah of pesantren of Nurul Yaqin is not given to the institution and tuangku or buya as educators. However, Niimma points out that pakiah of other traditional boarding schools outside Nurul Yaqin give the sadakah to their teachers or Tuangku. This is certainly intended as a gratitude to the teacher. ${ }^{53}$ The assumption of Niima is justified by Yurnalis, a resident in Pariaman. She understands that most of pakiah come from poor families but have a strong desire to study religion at the surau. Nevertheless, a general assumption in the community assumes that sadakah actually should be given to tuangku or buya. ${ }^{54} \mathrm{~A}$ different opinion is stated by Ronald. He says that not all pakiah come from poor families. There are some pakiah whose parents are Civil Servants, so, when they obtain sadakah, they would share with their poorer fellow. ${ }^{55}$ What is revealed by Yurnalis and Ronal above is the view of outsiders who expressed his perspectives on sadakah. They have never been pakiah, they just the givers of sadakah.

According to Tuangku Genta, a pakiah of Pesantren Madinatul Ilmi Islamiyyah, sadakah obtained from mamakiah is only used to fulfill his own needs, for example, for paying monthly dues of mangaji as much as IDR30.000,00 and two liters of rice. The rests are used for others necessities, such as for food and the ingredients to be cooked. ${ }^{56}$ This assumption is also justified by Efri, a former pakiah. Efri adds the books, Muslim clothing, sarongs, and the cap he has come from sadakah. All of these necessities should be used for the sake of education in the surau. In short, the results of mamakiah are not given to buya or other pesantren's managements as revealed by Niimma. Because mamakiah is linked to a practice that results in sadakah, of course, there are also some pakiah who use the sadakah not for the aforementioned purposes, such as for buying mobile phones and motorcycles. ${ }^{57}$

On another occasion, Tuangku Aznam also reveals that a pakiah with initial L is highly skilled in mamakiah. The technique he applies is by doing the mamakiah during the day and then meets with the mosque board in the area asking for an opportunity to give a lecture in the evening. Similar thing he applies in almost every mosque and surau in the area of the object of mamakiah. The local community feels so closed to this pakiah. He gets sadakah quite a lot so he can buy books, clothes, and all he needs for mangaji and giving lectures. ${ }^{58}$ The different assumptions develop in the community and the reality experienced by pakiah

\footnotetext{
${ }^{53}$ Niimmasubhani, "Tradisi Mamakiah..."

${ }^{54}$ Interview with Yurnalis, August 14, 2016.

${ }^{55}$ Interview with Ronal, August 11, 2016.

${ }^{56}$ Interview with Genta, September 24, 2016.

${ }^{57}$ Interview with Joni (not the real name), September 22, 2016.

${ }^{58}$ Materials for Forum Group Discussion by Tuangku Aznam, September 24, 2016.
} 
at least give us an idea that pakiah in the community are still needed even though there is some rather negative view in terms of how the pakiah spend the sadakah they earn.

\section{Conclusion}

Mamakiah tradition has existed since Islam introduced by by Shaikh Burhanuddin in Ulakan Padang Pariaman, West Sumatra in the fifteenth century. This tradition was developed by the students who mangaji in surau and they came from Siak. Therefore, the pakiah is also called urang siak. Mamakiah activity is held on Thursdays and Fridays. The identity of pakiah is known from a batik shirt or a muslim cloth, sarong, and black cap he wears, and buntia, flour sacks made of cloth. The buntia is used to bring gifts or sadakah of society such as rice and other items for daily needs. This phenomenon seems to be similar to the tradition of monks in Buddhism like in Thailand, who believe that they live for the people and teach the people to give charity for the monks.

The motivation of pakiah in doing mamakiah is driven by cultural, economic, and religious belief factors. Pakiah which are generally students of boarding schools are tempted to do mamakiah because they 'jump on bandwagon' and are invited by their seniors. After enjoying sadakah, they go mamakiah on their own. Senior pakiah are mostly motivated to do mamakiah to train to be mentally strong in order to be ready to live in society. The second is economic factor, in which many students who mangaji in surau such as the Pesantrens of Madinatul Ilmi Islamiyyah and Nurul Yaqin come from low economic level families and from outside Padang Pariaman. The last factor is their understanding of the religion they gain from Islamic literature they are studying in the boarding schools. An understanding of the importance of giving charity, especially to students studying religion, is a part of the religious messages delivered by a buya in his lectures in the community.

The views of the society on pakiah and sadakah can be classified into two categories. First, those who see it positively and believe that pakiah is físabîlillâh, people who study religion and lack of funds. Therefore, it is recommended to give sadakah to the pakiah. In addition, in essence, mamakiah is an attempt to invite people to give charity and pakiah helps them in the distribution of their sadakah. Second, those who view mamakiah negatively and percieve pakiahs as beggars. As such, their action contradicts religious teaching to give rather than to ask for sadakah. To the society at large, another important aspect of the argument is whether the sadakah of mamakiah is given to tuangku or buya in pesantren. Most tuangkus, however, argue that pakiahs do mamakiah merely to sopport their studies not to collect sadakah for theif tuangkus. Pesantren and suraus essentially neither prohibits nor sanctions pakiahs to do mamakiah.

Having said that, it seems in order to put forward some recommendations. Pesantren and suraus clearly need some financial support both from the government and the society at large. Sufficient financial support will allow this traditionsl indigineus education to prosper 
and provide a better education. Mamakiah has positive sides, because it could facilitate people to give sadakah and provide socio-psychological training for pakiahs santris. It should, however, be performed in well-mannered ways in accordance with the dignity of the pakiahs as students of relilgious knowledge and as future religious leaders.

\section{References}

Arinda R., Ichmi Yani. "Sedekah Bumi (Nyadran) sebagai Konvensi Tradisi Jawa dan Islam Masyarakat Sraturejo Bojonegoro," in el-Harakah, Vol. 16, No. 2, 2014.

Azra, Azyumardi. Islam Subtantif: Agar Umat tidak Menjadi Buih. Bandung: Mizan, 2010.

Azra, Azyumardi. Surau Pendidikan Islam Tradisional dalam Transisi dan Modernisasi. Jakarta: Logos, 2003.

Bourdieu, Pierrie. Distinction: A Social Critique of the Judgement of Taste. New York: Routledge, 2006.

Dhofier, Zamakhsyari. "Kinship and Marriage among the Javanese Kyai," in Indonesia, No. 29, (April 1980).

Dhofier, Zamakhsyari. Tradisi Pesantren: Studi Pandangan Hidup Kyai dan Visinya Mengenai Masa Depan Indonesia. Jakarta: LP3ES, 2011.

Erricker, Clive. "Pendekatan Fenomenologis," dalam Peter Connolly (ed.), Aneka Pendekatan Studi Agama, trans. Imam Khoiri, ed. 3. Yogyakarta: LKiS, 2011.

Hanani, Silfia, et al., "Surau Minangkabau, Mengembalikan Pendidikan Agama Islam Berbasis Lokal," in Istiqra': Jurnal Penelitian Islam Indonesia, Vol. III, No. 01, 2004.

Hidayatulloh, Furqon Syarief. "Sedekah Bumi Dusun Cisampih Cilacap," in el Harakah, Vol. 15, No. 1, 2013.

Jenkins, Richard. Membaca Pikiran Pierre Bourdieu, trans. Nurhadi, ed. 6. Yogyakarta: Kreasi Wacana, 2013.

Johnson, Randal. "Pengantar Pierre Bourdieu tentang Seni, Sastra dan Budaya," in Arena Produksi Kultural: Sebuah Kajian Sosiologi Budaya, trans. Yudi Santosa, ed. 3. Yogyakarta: Kreasi Wacana, 2015.

Khatib, al-, Muhammad al-Syarbaini, al-Iqnâ؛. Beirut: Dâr a-Fikr, 1415.

Moleong, Lexy J. Metode Penelitian Kualitatif. Bandung: Remaja Karya, 1989.

Niimmasubhani. "Tradisi Mamakiah dan Dampaknya terhadap Internal dan Eksternal Kelembagaan Pondok Pesantren Nurul Yaqin Ringan-Ringan Pakandangan Kabupaten Padang Pariaman.” Thesis, Post Graduate of IAIN Imam Bonjol Padang, 2010.

Pohl, Florian. Islamic Education and Civil Society: Reflections on the Pesantren Tradition in Contemporary Indonesia," in Comparative Education Review, Vol. 50, No. 3, (August 2006).

Rahardjo, Dawam. "The Life of Santri Youth: A View from Pesantren Window at Pabelan," in Sojourn: Journal of Social Issues in Southeast Asia, Vol. 1, No. 1 (February 1986). 
Samad, Duski dan Salmadanis. Surau di Era Otonomi. Jakarta: The Minangkabau Fondation, 2001.

Samad, Duski. Kontuinitas Tarekat di Minangkabau. Padang: TMF PRESS, 2006.

Saxebøl, Torkil. "The Madurese Ulama as Patrons, a Case Study of Power and Relations in an Indonesian Community". Dissertation, University of Oslo, 2002.

Turmudi, Endang. Struggling for the Ummah. Canberra: ANU Press, 2006.

Walbridge, Linda S. "The "Santri-Wati" of Indonesia's "Pesantren": Orientations of Students of Three Girls Religious Schools," in Islamic Studies, vol. 37, No. 4 (Winter 1988). 